\title{
COMPARATIVE STUDY OF THE CYTOTOXICTY AND GENOTOXICITY OF SILVER ZEOLITE AND NANO SILVER
}

\author{
Yousra Mohamed Nashaat", Soha A. Hassan ${ }^{* *}$, Ahmed hussien Labib ${ }^{* * *}$, \\ Mostafa shaker Elaasar ${ }^{* * * *}$ and Ahmed Maged Negm ${ }^{* * * * *}$
}

\begin{abstract}
Silver ions and Nano silver particles have a great importance as they used as root canal sealers due to their antimicrobial properties. However biocompatibility and satisfactory physico-chemical properties should be achieved to directly contact the root canal sealers with the surrounding tissues. This study aimed to compare the cytotoxicity and genotoxicity of silver-zeolite with silver nanoparticles. MRC-5 cell line was used as an in vitro model. The cell viability was assessed using MTT cytotoxicity assay. Genotoxicity was tested by alkaline single cell gel electrophoresis (comet assay) for measuring DNA damage. Each material was tested in different concentrations $(100 \mathrm{mg} / \mathrm{ml}, 50 \mathrm{mg} / \mathrm{ml}, 25 \mathrm{mg} / \mathrm{ml}, 12.5 \mathrm{mg} / \mathrm{ml}$, and $6.25 \mathrm{mg} / \mathrm{ml})$. The results showed that silver zeolite has lower cytotoxic effect than silver nanoparticles among all different concentrations used in the study. Also the results showed unaccepted cytotoxicity levels for silver nanoparticles on concentrations of $100 \mathrm{mg} / \mathrm{ml}$ and $50 \mathrm{mg} / \mathrm{ml}$. Data obtained from the Comet assay indicated that both silver nanoparticles and silver zeolite causes DNA damage with no significant difference between the two treated groups.
\end{abstract}

\section{INTRODUCTION}

Microorganisms that invades the complex root canal system may cause pulpal and periapical pathosis due to interaction with host. ${ }^{(1,2)}$ A significant goal of root canal treatment is the removal of bacteria from the root canal and prevention of subsequent reinfection. ${ }^{(1,3-5)}$ This is achieved by a thorough bio-mechanical cleaning of the root canal followed by the complete filling of the canal space. ${ }^{(3)}$ Enhancing the rate of success of root canal treatment can be achieved by sealing materials that exhibit both antibacterial properties as well as high sealing ability.

During endodontic treatment, procedures of cleaning and shaping eliminates microorganisms from the complex root canal system. However,

\footnotetext{
*Associate Professor of Endodontics, October 6 University ** Associate Professor of Cell Biology, October 6 University *** Associate Professor of Endodontics Tanata University **** Lecturer of Endodontics; October 6 University ***** Lecturer of Endosontics; Ahram Canadian University
} 
it is not possible to completely remove all the bacteria $^{(6)}$. In such cases sealing materials that have antimicrobial properties is more desirable.

The goal of endodontic treatment is not only to eliminate bacteria from the root canal complex, but also to prevent re-infection. ${ }^{(7)}$

The sealing agents used for root canal system obturation should establish a fluid tight seal of the roots apical area. To achieve this microorganisms growth inhibition is required.

Grossmann stated that among the ideal requirements of root canal obturating materials is the inhibition of microorganisms growth with good biocompatibility and not irritant to the peri-radicular tissue. ${ }^{(8)}$

Antimicrobial properties of these sealers will ensure elimination of microbes as well as prevent re-infection. Root canal sealers should ideally have satisfactory physio-chemical properties and excellent biocompatibility. Since these materials contacts the periapical tissue directly their biocompatibility and periradicular tissue tolerance are of primary importance. ${ }^{(9)}$

Silver was the antiseptic agent of choice prior the invention of antibiotics. ${ }^{(10)}$ With nanotechnology and its advancement, nano-silver particles are broadly used in the medical field, including antibacterial coatings of medical devices, wound dressing and creams. ${ }^{(11)}$ Because nano sized materials gives larger surface area which enhance their antibacterial effect rather than its bulk solid form, which led to the use of nano-silver particle as a potential irrigating chemical.

Zeolites are aluminosilicate solids with structures based upon a three dimensional ceramic framework. Therefore, they have micropores that are constructed by connecting many small cages. Silver ions locate at specific positions within the interior of the cage because of the surrounding electron density. ${ }^{(5,12,13)}$
Silver zeolite was presented as a crystalline alumino silicate material with silver ions having antimicrobial effect against almost all microbes yet the release of silver ions may lead to some cytotoxic effects. ${ }^{(14)}$

\section{MATERIALS AND METHODS}

\section{Cell Cultures}

MRC-5 cell line were supplied from VACSERA company, Giza, Egypt. Cells were grown in $75 \mathrm{~cm} 2$ cell culture flasks containing culture media until confluent monolayer was obtained. The medium used was 71\% Dulbecco's modified Eagle's medium (DMEM) (Sigma, Dorset, England, U.K.), 17.5\% Medium 199 (Sigma/Aldrich, USA) ${ }^{(15)}$, 9\% foetal calf serum (FCS) (Sigma/Aldrich, USA), 1.6\% 200 mM L-glutamine (Sigma/Aldrich, USA), and 0.9\% 100mM Sodium Pyruvate (Sigma/Aldrich, USA).

\section{Tested Materials}

1) Nano-silver*

2) Dental silver containg zeolite**

*) NanoTech Center (Dreamland, 6 Oct, Cairo) in a concentration of $2200 \mathrm{part} / \mathrm{million}$

**) Inventor Xuejun Qian, Foothill Ranch, CA(US)

- Asignee: Kerr Corporation, Orange, CA (US)

\section{Preparation of tested materials:}

The tested materials were divided as follow:

a) Group A: Silver nano-particles were added to the well plates with five different concentrations $(100 \mathrm{mg} / \mathrm{ml}-50 \mathrm{mg} / \mathrm{ml}-25 \mathrm{mg} / \mathrm{ml}-12.5 \mathrm{mg} / \mathrm{ml}$ $-6.25 \mathrm{mg} / \mathrm{ml})$

b) Group B: Silver zeolite particles were added to the well plates with five different concentrations $(100 \mathrm{mg} / \mathrm{ml}-50 \mathrm{mg} / \mathrm{ml}-25 \mathrm{mg} / \mathrm{ml}-12.5 \mathrm{mg} / \mathrm{ml}$ $-6.25 \mathrm{mg} / \mathrm{ml})$

The tested materials were prepared using a modified method; $1 \mathrm{mg}$ of each concentration of 
tested materials was mixed under aseptic conditions with $1 \mathrm{ml}$ of full-growth medium. Then, the tested materials were placed in a 24-well plate and incubated for $24 \mathrm{~h}$ at $37{ }^{\circ} \mathrm{C}$ in $5 \% \mathrm{CO} 2$ atmosphere after which the supernatant was carefully removed and submitted to serial dilutions in full-growth medium with concentrations $1 \mathrm{mg} / \mathrm{ml}$ for each tested material and then were used immediately for cytotoxicity assay.

\section{MTT cytotoxicity study ${ }^{(16)}$}

The MTT (3-(4,5-dimethylthiazol-2-yl)-2,5diphenyltetrazolium bromide) assay is a nonradioactive colorimetric assay used for measuring cell proliferation, viability or cytotoxicity. MTT is a water-soluble, yellow, tetrazolium salt. Metabolically active cells are able to convert this dye into a water-insoluble dark blue formazan by reductive cleavage of the tetrazolium ring [19]. Formazan crystals can then be quantified and dissolved by measuring the absorbance of the solution at $550 \mathrm{~nm}$, and the resultant value is related to the number of living cells.

\section{Procedure}

Cells were detached after trypsinisation and suspended. Cells were seeded at a density of 1.0 $\mathrm{x} 104$ cells/well in $100 \mu \mathrm{l}$ full-growth medium (DMEM + $10 \%$ FBS + antibiotics) in 96-well plates for 24 hours, then growth medium was replaced and removed with $100 \mu \mathrm{l}$ medium containing different tested materials. The cytotoxicity of the tested materials was determined after 24 hours incubation with MRC-5cell line. $20 \mu \mathrm{l}$ of MTT dye solution $(5 \mathrm{mg} / \mathrm{ml}$ in phosphate buffer $\mathrm{pH}-7.4)$ was added to each well.

The incubation was done at $37^{\circ} \mathrm{C}$ and $5 \% \mathrm{CO} 2$ for 4 hours, then the medium was removed and formazan crystals were solubilized with $200 \mu$ l of DMSO after which the reacted dye was dissolved by vigorously mixing the solution. A microplate reader (DYNATECH MR7000 instruments) at 550 $\mathrm{nm}$ was used to read the absorbance of each well.

Cytotoxicity was rated based on cell viability; means and standard deviations were calculated for each group and statistically analyzed to determine the presence or absence of significant differences.

\section{Analysis of DNA damage by comet assay}

Frosted glass microscopic slides firstly were coated by dipping in normal melting point agarose NMPA and air dried . different groups of MRC-5 cell suspension $(100 \mu 1)$ were mixed with $100 \mu 1$ of low melting agarose (1\% in PBS). $0.1 \mu 1$ of the resulted mixture was added to the perviously coated slide and covered with cover slip immediately and kept in dark at $4 \mathrm{C}^{\mathrm{o}}$ for 10 minutes to allow solidification of agarose. Cover slip was then removed and the slides were placed in lysis buffer $[2.5 \mathrm{~mol} / \mathrm{L} \mathrm{NaCl}$, $100 \mathrm{mmol} / \mathrm{L} \mathrm{Na} 2$ EDTA, $10 \mathrm{mmol} / \mathrm{L}$ Tris, $(\mathrm{pH}$ 10)] with freshly added $1 \%$ Triton $\mathrm{X}-100$ and $10 \%$ DMSO for at least 1 hour at $4 \mathrm{C}^{\circ}$.The slides were incubated for 10 minutes at $4 \mathrm{C}^{\circ}$ in electrophoresis chamber with electrophoresis alkaline buffer $(\mathrm{pH}>$ 13) for unwinding of DNA and allowing expression of alkali labile site. The electrophoresis was carried out for 20 minutes at low voltage $(25 \mathrm{~V}, 300 \mathrm{~mA}$, $4 \mathrm{C}^{\circ}$ ). Subsequently the slides were washed for three times, 5 minutes for each with neutralization buffer and stained with ethidium bromide ( $2 \mathrm{mg}$ / $\mathrm{mL}$ ), covered with a cover slip and observed at 40x objective using fluorescence microscope. Komet 5 image analysis software developed by Kinetic Imaging, Ltd. (Liverpool, UK) linked to a CCD camera were used to assess DNA damage. The images were examined; the length of DNA migration (tail length) was measured. The percentages of DNA in the tail were calculated for all cell groups. The tail moment, expressed in arbitrary units, was calculated as: tail length $\mathrm{X}$ percentage of migrated DNA / 100. Generally, 50 to 100 randomly selected cells were analyzed per sample. 


\section{RESULTS}

\section{Statistical analysis}

Data were expressed as means \pm SD. Test of normality, Kolmogorov-Smirnov test, was used to measure the distribution of data. Accordingly, data were not normally distributed, so comparison between values of measured at different concentrations in the in two studied groups were performed using Mann-Whitney U test. Statistical Package for Social Sciences (SPSS) computer program (version 19 windows) was used for data analysis. $\mathrm{P}$ value $\leq 0.05$ was considered significant.

On comparing the cytotoxicity of different concentrations of Group A ( Nano-Silver) the results showed that decreasing the concentration of silver nanoparticles affect significantly the cytotoxicity at the whole group where cell viability increases on decreasing the concentration of silver nanoparticles.

On comparing the cytotoxicity of different concentrations of Group B (Silver Zeolite) the results showed that decreasing the concentration Silver zeolite) there was no significant difference among the whole group on decreasing the concentration from 100 to 6.25 where the decrease of concentration causes steady decrease in the cytotoxicity each time the concentration decreased.

TABLE (1) Comparison between values of cell viability indicated by MTT assay in the two studied groups measured at different concentrations.

\begin{tabular}{|c|c|c|c|c|}
\hline Concs. & Nanoparticles $(\mathbf{n}=\mathbf{5})$ & Zeolite $(\mathbf{n}=\mathbf{5})$ & $\mathbf{Z}$ test & p value \\
\hline $\mathbf{1 0 0}$ & $44.91 \pm 3.75$ & $74.97 \pm 3.14$ & -2.611 & $0.009 *$ \\
\hline $\mathbf{5 0}$ & $65.40 \pm 3.65$ & $85.80 \pm 3.27$ & -2.611 & $0.009 *$ \\
\hline $\mathbf{2 5}$ & $71.00 \pm 5.92$ & $80.80 \pm 5.40$ & -2.095 & $0.036^{*}$ \\
\hline $\mathbf{1 2 . 5}$ & $78.00 \pm 4.06$ & $87.80 \pm 5.54$ & -2.193 & $0.028^{*}$ \\
\hline $\mathbf{6 . 2 5}$ & $83.00 \pm 4.69$ & $97.80 \pm 5.76$ & -2.514 & $0.012^{*}$ \\
\hline
\end{tabular}

Data are expressed as mean $\pm S D$.

p $>0.05=$ not significant .

$* p<0.05=$ significant .

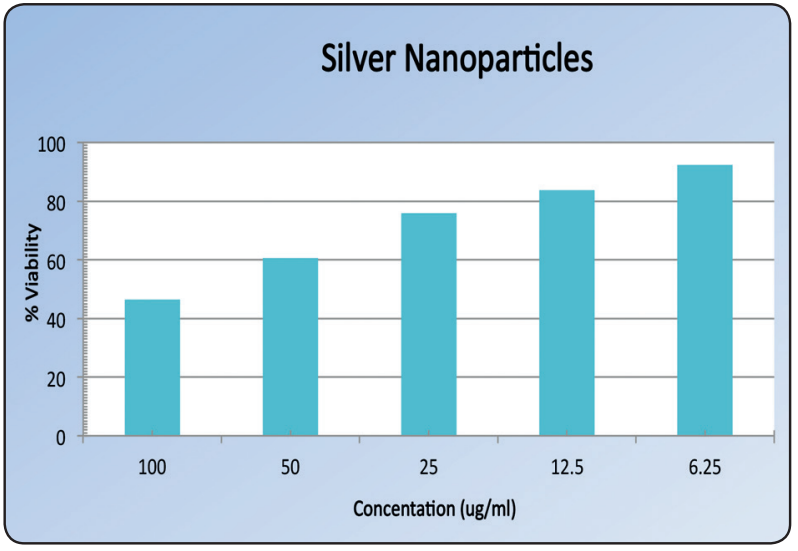

Fig (1): Bar-chart showing comparison between different concentrations of silver nanoparticles

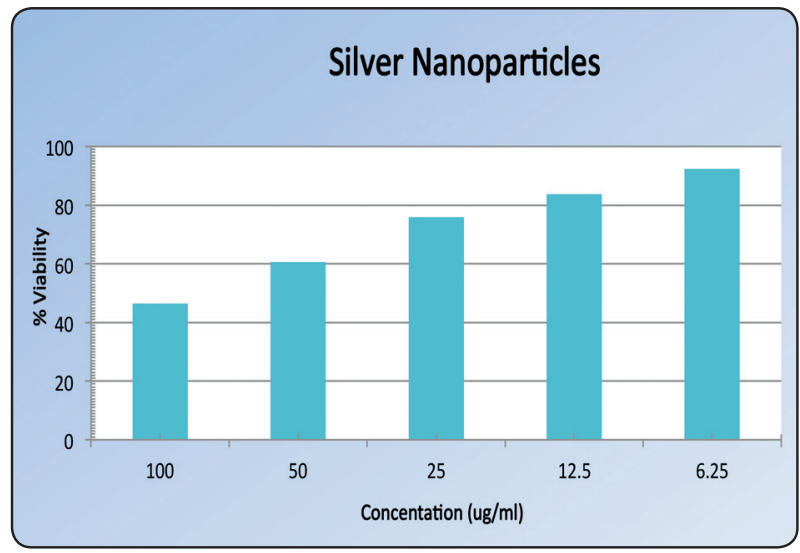

Fig (2): Bar-chart showing comparison between different concentrations of silver zeolite 


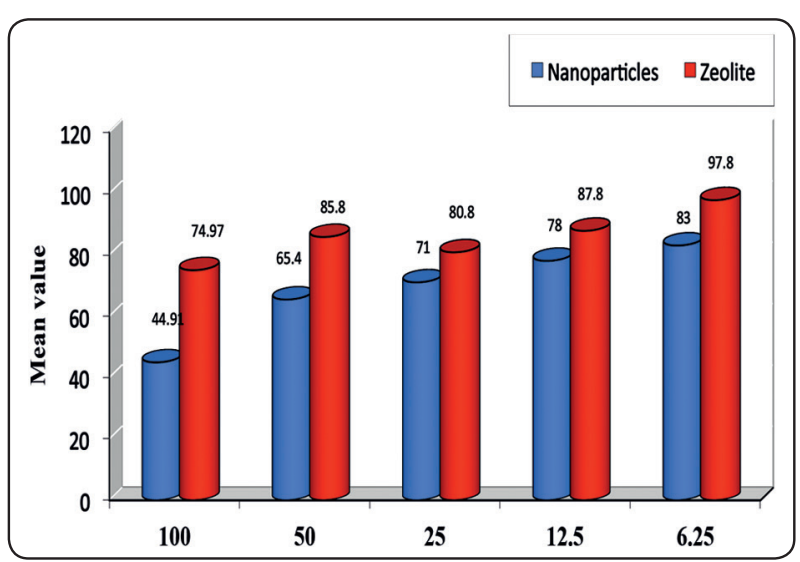

Fig (3): Bar-chart showing comparison between values of cytotoxicity in the two studied groups measured at different concentrations

On comparing the cytotoxicity of the two groups on different concentrations Silver Zeolite showed significantly higher cell viability than nano-silver in all concentrations.

The results of DNA damage by Comet assay showed elevation of tail moment unit in both silver zeolite and nanosilver treated groups when compared with normal. T.M-U unit express the amount of DNA damage, and it was calculated. For each cell, the length of DNA migration $(\mathbf{T} . \mathbf{L} \mu \mathbf{m})$ was measured as the distance between center of the nucleus to the end of the tail. The percentage of DNA(T.DNA\%) in the tail was calculated by measuring the total intensity (fluorescence) in the cells, which was taken as $100 \%$, and determining what percentage of this total intensity corresponded

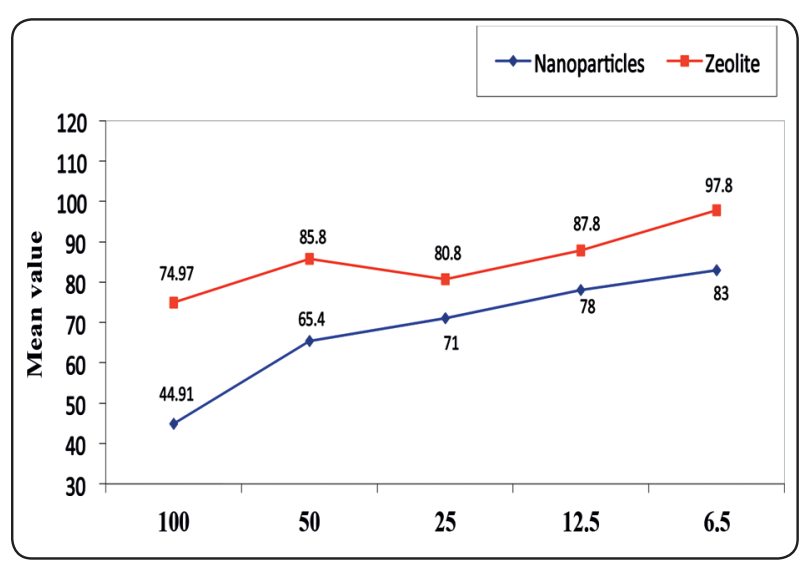

Fig (4): Linear chart showing comparison between values of cytotoxicity in the two studied groups measured at different concentrations

to the intensity measured only in the tail. The tail moment, expressed in arbitrary units, was calculated as: tail length $\mathrm{X}$ percentage of migrated DNA / 100.

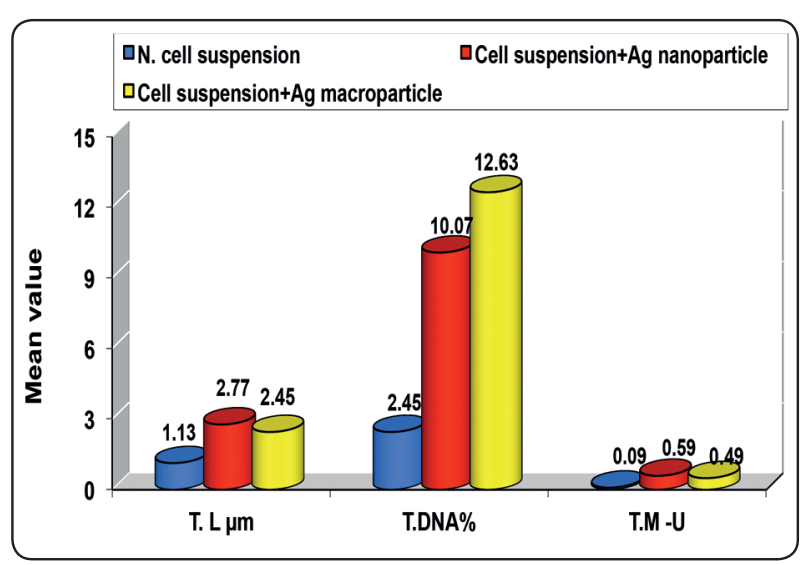

Fig. (5): Mean values of comet tail length (T.1), density of DNA and tail moment unite (T.M-U) in the three studied groups.

TABLE (2): Values of mean tail DNA\% (damage), tail length and tail moment of comets. Significant difference is indicated by superscript letter

\begin{tabular}{|l|l|c|c|c|}
\hline No. & Groups & T. $\mathbf{~} \boldsymbol{\mu} \mathbf{m}$ & T.DNA \% & T.M $-\mathbf{U}$ \\
\hline (I) & Normal cell suspension & $1.13 \pm 0.14^{\mathrm{b}}$ & $2.45 \pm 0.45^{\mathrm{b}}$ & $0.09 \pm 0.03^{\mathrm{b}}$ \\
\hline (II) & Cell suspension +Ag-Nanoparticles $(36.26 \mu \mathrm{g} / \mathrm{ml})$ & $2.77 \pm 0.30^{\mathrm{a}}$ & $10.07 \pm 0.56^{\mathrm{a}}$ & $0.59 \pm 0.04^{\mathrm{a}}$ \\
\hline (III) & Cell suspension +Ag-Macro particles $(131.101 \mu \mathrm{g} / \mathrm{ml})$ & $2.45 \pm 0.17^{\mathrm{a}}$ & $12.63 \pm 1.04^{\mathrm{a}}$ & $0.49 \pm 0.02 \mathrm{a}$ \\
\hline P-VALUE & $<0.001<\mathbf{0 . 0 0 1}$ & $<0.001$ & $<0.001$ & $<0.001$ \\
\hline
\end{tabular}




\section{DISCUSSION}

It is crucial for the outcome of the root canal treatment to successfully eliminates microbes from the necrotic root canal space avoiding contamination of apical tissue, which can be managed clinically ${ }^{(17)}$.

The best way used for bacterial reduction in the root canal apical region, is achieved mechanically by instrumentation accompanied by antibacterial irrigating solutions. ${ }^{(18,19)}$

Recently it was stated that silver ions minimize the growth of bacteria by binding to thiol groups $(-\mathrm{SH})$ in enzymes causing their deactivation. Silver forms stable S-Ag bonds with compounds containing thiol in the cell membrane which are involved in ion transport and energy generation. ${ }^{(20)}$

Silver containing compounds were used for maintaining the antimicrobial activity, ${ }^{(1,21)}$ because of their strong antimicrobial activity, high stability, and wide antibacterial spectrum. For the preparation of such materials, zeolites have been used as the host inorganic compound. Silver zeolite consists of a crystalline aluminosilicate zeolite, which forms the skeleton of silver zeolite and permits ion exchange. Of the several cations that bind to zeolite $(\mathrm{Ag}+, \mathrm{Zn++}$, etc.), silver ions have been widely used in medicine as an antimicrobial agent and bind to zeolite resulting in a gradual, stable, and longlasting release of silverions. ${ }^{(22)}$

Nano silver which is a metallic silver is distributed uniformly on the surface of the dental materials. It does not cause its corrosion or changes its color. The addition of Nano silver into the root canal filling materials prevents further spread of bacteria and is highly biocompatible. ${ }^{(23)}$

ISO recommended $(10993-5,2009)$, that the cell viability if less than $70 \%$, it would be considered as cytotoxic to that type of cell. ${ }^{(24)}$

According to the ISO recommendation Silver nanoparticles in the concentrations of $100 \mu \mathrm{g} /$ $\mathrm{ml}$, and $50 \mu \mathrm{g} / \mathrm{ml}$ were stated to be cytotoxic as the results of cell viability of these concentrations were below $70 \%$. While silver zeolite wasn't cytotoxic in all concentrations used starting from the highest concentration $100 \mu \mathrm{g} / \mathrm{ml}$, till the lowest concentration $6.25 \mu \mathrm{g} / \mathrm{ml}$ where the mean of cell viability percentages were above $70 \%$.

The results came in conjugation with Kawahara et al. (12) who stated that when incorporating zeolite in tooth pastes with no toxicity similar to the concentrations in the MIC assays, it would be a promising additives to incorporate into dental materials, especially when used in periodontal pockets.

This was also corresponding to Thom et al. ${ }^{(5)}$ who also proved that $0.2 \%$ Zeolite containing root canal filling material showed less cytotoxicity than AH 26 and have characteristics similar to the glass ionomer cements formulations tested.

Increasing the concentration of silver zeolite in this study lead to increasing the cytotoxicity, this came in conjugation with Abe et al. ${ }^{(14)}$ who found that cell viabilities for Visco-Gel, GC Soft-Liner, FITT, and SR-Ivoseal decreased with increasing silver-zeolite content.

The alkaline comet assay used after Singh et al ${ }^{(25)}$ allow the the alkali labile sites of DNA to be expressed and comet tails appears through electrophoresis indicating DNA damage. Silver zeolite and nanosilver treated groups showed significant elevation of tail moment versus control group, however no significant difference occured between silver zeolite and nanosilver treated group.

Nano silver can be taken up by many different

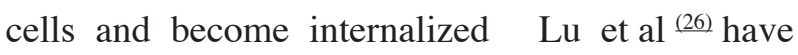
found that uptake of nanosilver by human skin keratinocytes depends on the shape and size of the nanoparticles and incubation time.

Nano silver interacts with DNA and cause DNA damage. Rahban et al $\stackrel{(27)}{ }$ have tested the nanosilver interaction with DNA of calf thymus and found 
tight bond. Another studies have investigated DNA damage caused by nanosilver $\stackrel{(28}{2}, 29$. In the study by Hackenberg et al $\stackrel{(26)}{ }$, investigation of DNA damage were tested using human mesenchymal stem cells. Short exposure and incubation of 24 hours induced significant time-dependant DNA damage. Their conclusion was, direct interaction of nanosilver may induce genotoxicity.

Neutrophils and macrophages exposed to nanoparticles cause inflammation that generate oxidative DNA damage due to Reactive Oxygen Species ROS formation $(\underline{30)},(31),(32)$.

Our results confirmed previous studies and explained the damage in DNA in form of tail length and DNA intensity calculated as moment unit.

The nanosilver particles as well as silver zeolite that causes mitochondrial dysfunction, generation of (ROS), by entering the cell through endocytosis and diffusion leading to damages to nucleic acids and proteins, and inhibits proliferation of cells ${ }^{(33-37)}$. Oxidative stress occurs when generation of ROS exceeds the capacity of the cellular antioxidant defense system. Depletion of glutathione and protein bound sulf hydryl groups and changes in the activity of various antioxidant enzymes indicative of lipid peroxidation have been implicated in oxidative damage. ${ }^{(38-39)}$

\section{CONCLUSION}

No significant difference between silver zeolite and silver nano particles concerning their cytotoxicity and genotoxicity.

\section{REFERENCES}

1. Patel V, Santere JP, Friedman S. Suppression of bacterial adherence by experimental root canal sealers. J Endod 2000; 26:20-24.

2. Chung HA, Titly K, Torneckk CD, Lawrenc HP, Friedman $\mathrm{S}$. Adhesion of glass-ionomer cement sealers to bovine dentin conditioned with intracanal medications. J Endod 2001;27:85-88.
3. Abdulkader A, Duguid R, Saunders EM. The antimicrobial activity of endodontic sealers to anaerobic bacteria. Int Endod J 1996;29:280-283.

4. Shalhav M, Fuss Z, Weiss EI. In vitro antibacterial activity of a glass ionomer endodontic sealer. J Endod 1997;23:616-619.

5. Thom DC, Davis JE, Santere JP, Friedman S. The hemolytic and cytotoxic properties of a zeolite-containing root filling material in vitro. Oral Surg Oral Med Oral Pathol Oral Radiol Endod 2003;95:101-108.

6. El Karim I, Kenedy J, Hussey D. The antimicrobial effects of root canal irrigation and medication. Oral Surg Oral Med Oral Pathol Oral Radiol Endod.2007; 103:560-9.

7. Ray HA, Trope M. Periapical status of endodontically treated teeth in relation to the technical quality of the root filling and coronal restoration. Int Endod J. 1995;28(1):1218.

8. Grossman LI. Root canal therapy. Kimpton, London; 1940

9. Huang F, Tai K, Chou M and Chang Y. Cytotoxicity of resin, zinc oxide eugenol and calcium hydroxide based root canal sealers on human periodontal ligament cells and permenant V79 cells. Int Endod J 2002: 35:153-8.

10. Wjnhoven SW, Pijnenburg W, Herberts CA, et al. Nanosilver: A review of available data and knowledge gaps in human and environmental risk assessment. Nanotoxicology. 2009;3(2):109-138.

11. YouC, Han C, Wange X, et al. The progress of silver nanoparticles in the antibacterial mechanism, clinical application and cytotoxicity. Mol Biol Rep. 2012;39(9):9193-9201.

12. Kawahara K, Tsuruda K, Morishita M, Uchida M. Antibacterial effect of silver-zeolite on oral bacteria under anaerobic conditions. Dent Mater 2000;16:452-455.

13. Inoue Y, Hosheno M, Takahashe H, Noguche T, Murataa T, Kanzki Y, Hamashimaa H, Sasatsuu M. Bactericidal activity of Ag-zeolite mediated by reactive oxygen species under aerated conditions. J Inorg Biochem 2002;92:37-42.

14. Abee Y, Ueshiige M, Takeuche M, Ishi M and Akagawa Y. Cytotoxicity of antimicrobial tissue conditioners containing silver zeolite. Int J. Prosthodont 2003;16:141-4.

15. Silva E.J.N.L, De Carvalho N.K, Ronconi C.T, Zuolo M.L, and Zaia A.A. Cytotoxicity profile of Endodontic sealer provided by $3 \mathrm{D}$ cell culyur experimental model. Braz. Dent. J. 2016;27:652-6 
16. Zhangg W, Torabinejad M, and Li Y. Evaluation of cytotoxicity of MTAD using the MTT-Tetrazolium method. J. Endod. 2003;29:654-7.

17. Siqueira JF Jr, Rôcas IN. Clinical implications and microbiology of bacterial persistence after treatment procedures. J Endod. 2008; 43:1291-1301.

18. Bystrom A, Sundqvist G. The antibacterial action of sodium hypochlorite and EDTA in 60 cases of endodontic therapy. Int Endod J. 1985; 18:35-40.

19. Rocas IN, Siquera JE. Comparison of the in vivo antimicrobial effectiveness of sodium hypochlorite and chlorhexidine used as a root canal irrigants. A molecular microbial study. J Endod. 2011; 37:143-150.

20. Klueh U, Wagner V, Kelly S., Johnson, A, and Bryers, J.D. "Efficacy of Silver-Coated Fabric to Prevent Bacterial Colonization and Subsequent Device-Based Biofilm Formation. Journal of Biomedical Materials Research Part B: Applied Biomaterials. 2000; 53: 621-631.

21. Yoshida K, Tanagawa M, Matsumoto S, Yamada T, Atsuta M. Antibacterial activity of resin composites with silvercontaining materials. Eur J Oral Sci 1999;107:290-296.

22. Matsura T, Abe Y, Satoo Y, Okamooto K, Ueshege M, Akagawa Y. Prolonged antimicrobial effect of tissue conditioners containing silver-zeolite. J Dent 1997;25:373-377.

23. Tyagi S, Mishra P, Tyagi P. Evolution of root canal sealers: An insight story. Eur J Gen Dent 2013;2:199-218.

24. International Organization for Standardization. Biological Evaluation of Medical Devices-Part 5: Tests for In Vitro cytotoxicity ISO-10993-5; 2009 (en). 3rd ed. International Organization for Standardization; 2009.

25. Singh N.P., McCoy M.T., Tice R.R., Schneider E.L. A simple technique for quantitation of low levels of DNA damage in individual cells.Exp. Cell Res., 175 (1988), pp. 184-191

26. Lu W, Senapatii D, Wang S, Tovmaachenko O, Singhe AK, Yu H, Rayy PC. Effect of surface coating on the toxicity of silver nanomaterials on human skin keratinocytes. Chem Phys Lett. 2010;487:92-96.

27. Rahbann M, Divsalaar A, Sabuory AA, Golestanii A. Nanotoxicity and Spectroscopy Studies of Silver Nanoparticle: Calf Thymus DNA and K562 as Targets. J Phys Chem C. 2010;114:5798-5803.

28. Lim H, Asharanii P, Hande P. Enhanced genotoxicity of silver nanoparticles in DNA repair deficient mammalian cells. Front Genet. 2012;3:1-12.
29. Hackenberge S, Scherzede A, Kessleer M, Hummel S, Technau A, Froelich K, Ginzkey C, Koehler C, Hagen R, Kleinsasser N. Silver nanoparticles: evaluation of DNA damage, toxicity and functional impairment in human mesenchymal stem cells. Toxicol Lett. 2011;201:27-33.

30. Bresan E, Vindignii V, Ferronii L, Caiirns W, Gardinn C, Rigoo C, Zavann B, Stocchero M. Silver Nanoparticles and Mitochondrial Interaction. Int J Dentistry. 2013;2013:1-8.

31. Schinss RP, Knapen AM. Genotoxicity of poorly soluble particles. Inhal Toxicol. 2007;19:189-198.

32. He D, Jones A, Garg S, Pham A, Waite T. Silver Nanoparticle-Reactive Oxygen Species Interactions: Application of a Charging-Discharging Model.J Phys Chem C. 2011;115:5461-5468.

33. Hase A, Rot S, Mantiion A, Graff P, Plendl J, Thuenemann AF, Meier WP, Taubert A, Luch A, Reiser G. Effects of Silver Nanoparticles on Primary Mixed Neural Cell Cultures: Uptake, Oxidative Stress and Acute Calcium Responses. Toxicol Sci. 2012;126:457-468.

34. He D, Dorantes AJJ, Waite TD. Silver Nanoparticle-Algae Interactions: Oxidative Dissolution, Reactive Oxygen Species Generation and Synergistic Toxic Effects. Environ Sci Technol. 2012;46:8731-8738.

35. Roh JY, Eom HJ, Choi J. Involvement of Caenoihabditis elegans MAPK signaling pathways in oxidative stress Response induced by silver nanoparticles exposure. Toxicol Res. 2012;28:19-24.

36. Van Aerle R, Lange A, Moorhouse A, Paszkiewicz K, Ball K, Johnston BD, de-Bastos E, Booth T, Tyler CR, Santos EM. Molecular Mechanisms of Toxicity of Silver Nanoparticles in Zebrafish Embryos. Environ Sci Technol. 2013;47:8005-8014.

37. Li Y, Zhang W, Niu J, Chen Y. Surface-coating-dependent dissolution, aggregation, and reactive oxygen species (ROS) generation of silver nanoparticles under different irradiation conditions. Environ Sci Technol. 2013;47:10293-10301.

38. He W, Zhou YT, Wamer WG, Boudreau MD, Yin JJ. Mechanisms of the $\mathrm{pH}$ dependent generation of hydroxyl radicals and oxygen induced by Ag nanoparticles. Biomaterials. 2012;33:7457-7555.

39. Danielle Mc, Shan Paresh C, RayHongtao Yu . Molecular toxicity mechanism of nanosilver. Journal of Food and Drug Analysis Volume 22, Issue 1, March 2014, Pages 116-127 